\title{
Hematopoietic System Finding
}

National Cancer Institute

\section{Source}

National Cancer Institute. Hematopoietic System Finding. NCI Thesaurus. Code C36289.

Symptoms, physical examination results, and/or laboratory test results related to the hematopoietic system. 